\title{
IDENTIFICATION OF ARTIFICIAL GROUNDWATER RECHARGE ZONES IN VAVUNIYA DISTRICT USING REMOTE SENSING AND GIS
}

\author{
Ramya, $\mathbf{R}^{1}$, Nanthakumaran, $\mathbf{A}^{\mathbf{1}}$ and Senanayake, I $\mathbf{P}^{\mathbf{2}}$ \\ ${ }^{1}$ Department of Biological science, Vavuniya Campus of the University of Jaffna, \\ Vavuniya, Sri Lanka.
}

2Department of Earth Resources Engineering, University of Moratuwa, Colombo, Sri Lanka.

\begin{abstract}
Ground water is a major source for domestic and irrigation purposes in Sri Lanka and plays a crucial role to human life and economic activity. With rapid growth of population and urbanization water requirements for drinking and other purposes are dramatically increasing. The over extraction and unplanned development of ground water resources have led to considerable depletion of water resources. Artificial recharge is the practice of increasing the amount of water that enters groundwater reservoir by artificial means of planned human activity. The distribution and recharge of groundwater in the country varies significantly depending on geology, rainfall and geomorphology. The objective of this study was to identify artificial recharge potential. This study was conducted in Vavuniya district since the water shortage was observed over the years. Geomorphology, geology, soil, land use and stream data along with Landsat 7 ETM+ and DEM images were utilized to develop the relevant thematic layers such as geology, geomorphology, soil, slope, lineament density, land use and stream density by integrating GIS (Geographic Information System) and image processing techniques. The resultant thematic layers were utilized to prepare the groundwater recharge maps of the area through a weighted overlay method in a GIS platform. The results revealed that the artificial recharge was high in Southern part of the study area. Further the area has significant groundwater recharge zones which can be utilized for a sustainable ground water management system.
\end{abstract}

Key words: Artificial recharge potential, Geomorphology, GIS, Groundwater resource, Remote Sensing (RS), Sustainable water management,

\section{Introduction}

The world's total water resources were estimated as $1.3^{*} 108$ million ha-m. Out of this about $97.2 \%$ is salt water, in oceans and only $2.8 \%$ is available as fresh water at any time on the earth. About 2.2\% of fresh water is available as surface water whereas $0.6 \%$ as groundwater. Out of this surface water, $2.15 \%$ is fresh water in the form of glaciers and icecaps. About $0.01 \%$ is available in lakes and reservoirs and $0.0001 \%$ in streams, the remaining being in other forms (Raghunath, 1987).
Sri Lanka is enriched with surface water and ground water resources. Surface water bodies includes the radial drainage pattern that carries surface water down from the high watersheds includes 103 distinct natural river basins while groundwater resources are replenished by surface water and rainfall.

Groundwater is defined as subsurface water that fills all the pore space of soils and geologic formations below the water table (Freeze and Cherry 1979). Several factors affect the occurrence and

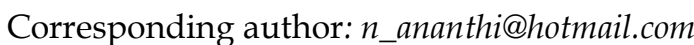
Received:07.11.2018
D http://orcid.org/0000-0003-0224-3957

Accepted: 26.12.2018 
movement of groundwater in a region including topography, lithology, geological structures, and depth of weathering, extent of fractures, primary porosity, secondary porosity, slope, drainage patterns, landform, land use/land cover, and climate.

Groundwater is the most important natural resource since it is a major source of drinking water where the surface water bodies are not much available. Groundwater is much reliable due to its cleaner nature caused by the filtering process of aquifers and also which can be used for domestic, commercial, industrial, agricultural purposes and also for small scale irrigation projects, water supply schemes. When surface water flows dry up in some periods of a year, groundwater is the only water supply source.

Groundwater and aquifer investigations and analysis in Sri Lanka has a major constraint of inadequate hydrogeological data. "Anyone attempting to formulate a national policy on groundwater development for the metamorphic rock regions of Sri Lanka confronted with enormous deficiencies in hydrological data" (Foster et al., 1976). Hence, the mapping of artificial recharge sites poses a major role in water resource management. These will be useful for the farmers and water supply schemes to nourish the groundwater reservoirs.

Generally in Sri Lanka water is distributed in major areas and urban cities through delivery pipes under the government drinking water supply schemes. In the rest of the areas people fulfill their requirement by open dug wells, irrigation channels, reservoirs, tanks, lakes, springs, rivers, streams, or by collecting rain water. In Sri Lanka especially, the towns of Jaffna, Batticaloa, Mannar, Vavuniya and Puttalam are more than 90 percent dependent on groundwater aquifers through municipal well fields and private boreholes (Panabokke, 2007).
Since 1970 rapid and heavy utilization of groundwater through well irrigation was observed in Vavuniya district. This may be because of unusual drought and the food crisis in the country forced Government to provide assistance through political authorities to open up "food production wells" (Madduma Bandara, 1979). Thus increased use of wells caused the increased exploitation of groundwater. So, the artificial recharge plays a major role for the sustainable management of groundwater.

Over $40 \%$ of the area in Asia are drought prone and require development of ground water resource (Sivakumar, 2008). Even in areas where the surface water supplies available through major, medium and minor irrigation projects, ground water are playing an increasingly vital role in supplementing surface water (Nagaraj \& Dewan, 1972). The increasing demand placed on it has led to investigations, towards augmentation of the resource.

To meet the growing demand for drinking, domestic and industrial sector and to address various issues related to ground water, there is a vital need to prepare a comprehensive map with identified strategies for scientific and sustainable management of the ground water resources. So, identifying groundwater artificial recharge zones can be vital to overcome the water scarcity in Vavuniya.

The prolonged drought conditions are common occurrence in Vavuniya as in other parts of dry zone. This water shortage still plays a role as a major constraint to agricultural development in this area. With the cultivable extent of 21,016 ha in Vavuniya district, only 16,599 ha was under cultivation in 2015 which is 78\% (Statistical handbook, 2015). The main reason for this situation could be the prevailing water shortage. Thus the development of groundwater resource has an important role in development of 
agriculture sector as well as industrial sector.

The objective of this study was to investigate and predict the groundwater artificial recharge zones using GIS techniques.

\section{Materials and Methods}

Remote Sensing (RS) and the Geographical Information System (GIS) have the advantages of spatial and temporal availability and facilitating the manipulation of data covering large and inaccessible areas within a short time.

Integrated remote sensing and GIS can provide the appropriate platform for analysis of diverse data sets for decision making in groundwater resource mapping and planning. This work aims to develop and apply integrated methods combining the information obtained by analyzing multi-source remotely sensed data in a GIS environment for better understanding of groundwater resource.

\subsection{Preparation of thematic layers}

Relevant thematic layers were developed such as geology, geomorphology, soil, slope, lineament density, land use and stream density. Geomorphological map of Sri Lanka (Verstappen and Hoschtitzky, 1987) and soil cover map (Land Use Division-Department of Irrigation Sri Lanka, 1988) was obtained from the European Soil Portal (European Soil
Portal, 2014) and digitized, later converted to raster to produce the Geomorphology and soil thematic layers. Lithology thematic layer was prepared by digitizing and rasterizing 1: 100,000 geology map of GSMB (Geological Survey and Mines Bureau of Sri Lanka). Drainage density layer was generated from drainage map which is digitized from 1: 50,000 topo sheet of Survey department by using spatial analyst tools in ArcGIS. Slope layer was generated from SRTM DEM $(30 \mathrm{~m})$ which was downloaded from USGS earth explorer, using spatial analyst tool. Lineament layer was prepared from automatically extracted lineaments from SRTM DEM (Weerasekara, et al., 2014) in the study area. Thereafter, the developed lineament layer was merged with the major lineaments in the geology map prepared by the Geological Survey and Mines Bureau of Sri Lanka. Lineament density map was prepared by using 'Spatial analyst' tool in Arcmap.

Multi-criteria evaluation technique was performed for all the thematic layers and their different classes. Each layer and class were assigned a weight based on the soil and land characteristics and using the available literature in the past and ranked depending on their suitability to hold ground water. All the thematic layers were then integrated in ArcGIS by using weighted overlay to produce groundwater prospects map.

Table 1. Ranks assigned for the thematic layers

\begin{tabular}{|c|c|}
\hline Criteria & Groundwater Recharging \\
\hline 1. Lithology & 15 \\
\hline 2. Geomorphology & 15 \\
\hline 3. Slope & 15 \\
\hline 4. Lineaments & 10 \\
\hline 5. Land use & 10 \\
\hline 6. Drainage Density & 10 \\
\hline 7. Soil & 5 \\
\hline
\end{tabular}

(Source: Modified from Basavaraj and Nijagunappa, 2011; Shahid et al, 2000; Kumar et al, 2007; Sarup et al, 2011; Jaiswal et al, 2003; Gunawardena and Dissanayake, 2007) 
Framework of methodology adopted for GIS modelling is shown below.

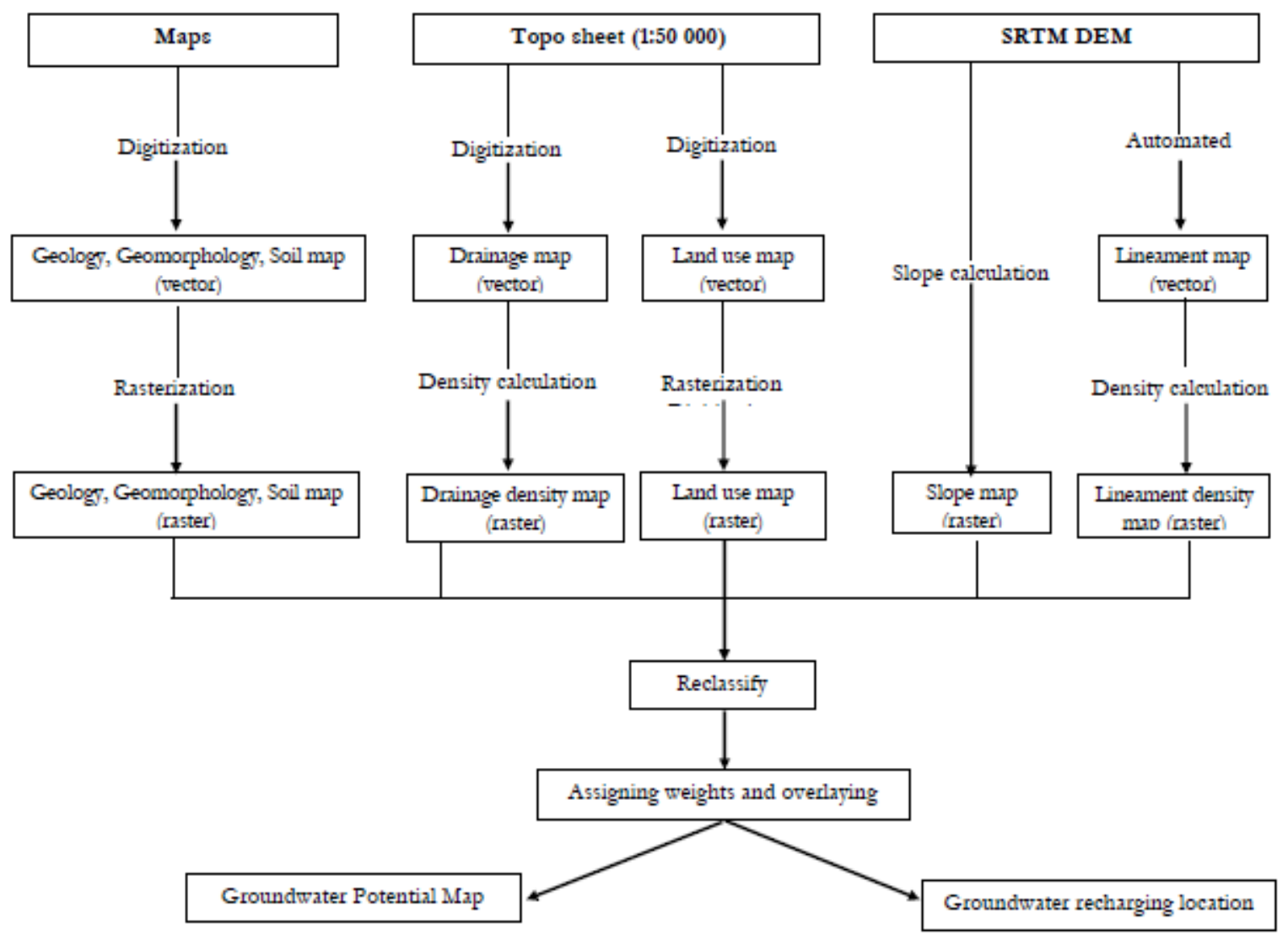

Fig 2. Flow chart of the methodology adopted to GIS modeling

Table. 1 Weights assigned for classes of each layer

\begin{tabular}{|l|c|}
\hline & $\begin{array}{c}\text { Groundwater } \\
\text { Recharging }\end{array}$ \\
\hline $\begin{array}{l}\text { 1. Geomorphology } \\
\text { Low plantation surface with inselbergs and thin }\end{array}$ & 3 \\
\hline Lower levels of intermediate Plantation surfaces & 5 \\
\hline Upwarped pleistocene coastal plain & 8 \\
\hline River plain & 7 \\
\hline 2. Soil & 6 \\
\hline Reddish Brown Earths \& Low Humic Gley soils & 4 \\
\hline Solodized Solonetz \& Solonchaks & 4 \\
\hline Alluvial soils & 2 \\
\hline Eroded land & 2 \\
\hline
\end{tabular}




\begin{tabular}{|c|c|}
\hline Erosoinal remnants & 2 \\
\hline 3. Lithology & \\
\hline Alluvium & 6 \\
\hline $\begin{array}{c}\text { Massive rock with less fractures } \\
\bullet \quad \text { Chanockite }\end{array}$ & 2 \\
\hline Chanockitic Gneiss and Chanockitic Biotite Gneiss & 2 \\
\hline $\begin{array}{l}\text { Dune Sand } \\
\text { Red beds }\end{array}$ & 8 \\
\hline $\begin{aligned} \text { Gneissic rock } & \\
\bullet & \text { Garnet Biotite Gneiss } \\
\bullet & \text { Garnetiferous-Quartzofeldspathic Gneiss } \\
\bullet & \text { Granite Gneiss } \\
\bullet & \text { Alkali-feldspar granite/gneiss/migmatite } \\
\bullet & \text { Biotite gneiss and granite }\end{aligned}$ & 3 \\
\hline $\begin{aligned} \text { Highly weathered rocks } \\
$\[ \text { Garnet Sillimanite Biotite Gneiss } \]$ \\
\bullet \text { Honblende Biotite Gneiss } \\
\bullet \text { Hornblende Gneiss (Amphibolite) } \\
\text { • Biotite hornblende }\end{aligned}$ & 4 \\
\hline Quartzite and quartz rich & 5 \\
\hline 4. Land use & \\
\hline $\begin{array}{c}\text { Plantation } \\
\bullet \quad \text { Other }\end{array}$ & 4 \\
\hline Chena & 5 \\
\hline Forest & 3 \\
\hline Grass Land & 3 \\
\hline Home Garden & 2 \\
\hline Marshy Land & 7 \\
\hline Paddy & 7 \\
\hline Rock & 2 \\
\hline Scrub & 5 \\
\hline $\begin{array}{c}\text { Water bodies } \\
\bullet \quad \text { Tanks }\end{array}$ & 8 \\
\hline - Tanks Abandon & 6 \\
\hline - Water Holes & 8 \\
\hline 5. Slope & \\
\hline $0-1$ & 9 \\
\hline $1-3$ & 8 \\
\hline $3-5$ & 6 \\
\hline $5-10$ & 4 \\
\hline $10-15$ & 3 \\
\hline $15-35$ & 1 \\
\hline
\end{tabular}




\begin{tabular}{|l|l|}
\hline \multicolumn{1}{|c|}{. Drainage density } & \\
\hline $0-0.5$ & 1 \\
\hline $0.5-1$ & 2 \\
\hline $1-2$ & 3 \\
\hline $2-3$ & 5 \\
\hline $3-5$ & 6 \\
\hline $5-7$ & 8 \\
\hline 7. Lineament density & \\
\hline $0-0.5$ & 1 \\
\hline $0.5-1$ & 4 \\
\hline $1-3$ & 6 \\
\hline $3-6$ & 7 \\
\hline
\end{tabular}

(Source: Modified from Basavaraj and Nijagunapa, 2011; Shahid et al, 2000; Kumar pet al, 2007; Sarup et al, 2011; Jaiswal et al, 2003; Gunawardena and Dissanayake, 2007; Senanayake. et al., 2015; Weerawarnakula (Personal communication, February 15, 2016))

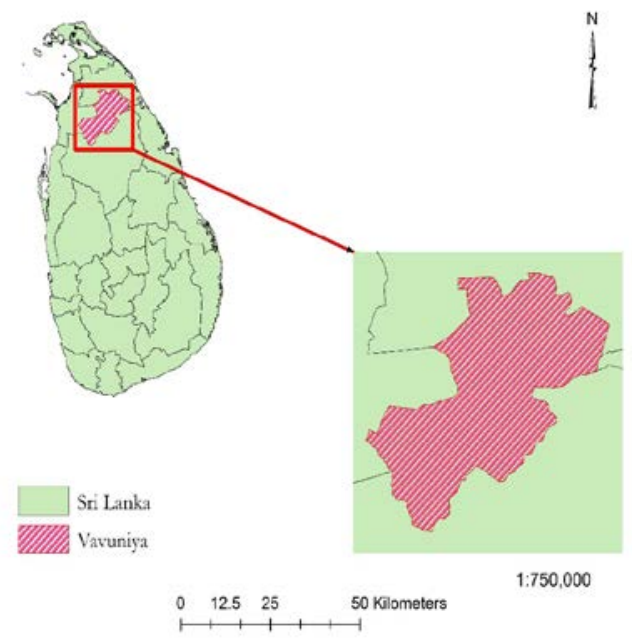

Fig.2. Location of Study area

\subsection{Study area}

Vavuniya District was selected as study area which is located in the North of Sri Lanka in the Northern Province. Geographically, the study area is situated between the latitude $8^{\circ} 50^{\prime} 0^{\prime \prime} \mathrm{N}$ and longitude $80^{\circ} 30^{\prime} 0^{\prime \prime} \mathrm{E}$ with the area of 1,967 square kilometres (759 sq mi).
Vavuniya is situated in the Dry zone of Sri Lanka. This district has 4 Divisional Secretary divisions and covers 102Grama Niladharies divisions and 505 villages with the population of 171,511 as per 2011 census of population.

\section{Results and Discussion}

The resulted combined image of automatically extracted lineaments and major lineament showed the total lineaments of study area. Figure 3 shows the generated lineaments map of study area.

The geomorphic units identified in the study area mainly composed of 'low plantation surface with inselbergs and thin soil' and the rest includes 'Lower levels of intermediate Plantation surfaces', 'Upwarped pleistocene coastal plain' and 'River plain and adjacent coastal lowlands'. The low plantation surfaces covered most part of the study area. Fig. 4 shows the geomorphologic map of study area.

Fourteen lithounits were observed in the study area which were Alluvium, Alkali 
feldsapr granitic/gneiss/migmatite, Chanockite, Chanockitic Gneiss and Chanockitic Biotite Gneiss, Dune Sand, Garnet Biotite Gneiss, Garnetiferous Quartzofeldspathic Gneiss, Granite Gneiss, Garnet Sillimanite Biotite Gneiss, Honblende Biotite Gneiss, Hornblende Gneiss (Amphibolite), Quartzite and quartz rich, Biotite gneiss and granite, Biotite hornblende, Red Beds. The study area was dominated by Quaternary deposits and Proterozoic metamorphic rocks. Fig. 5 shows the lithology map of study area.

Reddish Brown Earths \& Low Humic Gley soils: undulating terrain, Solodized

\section{Lineaments Map}

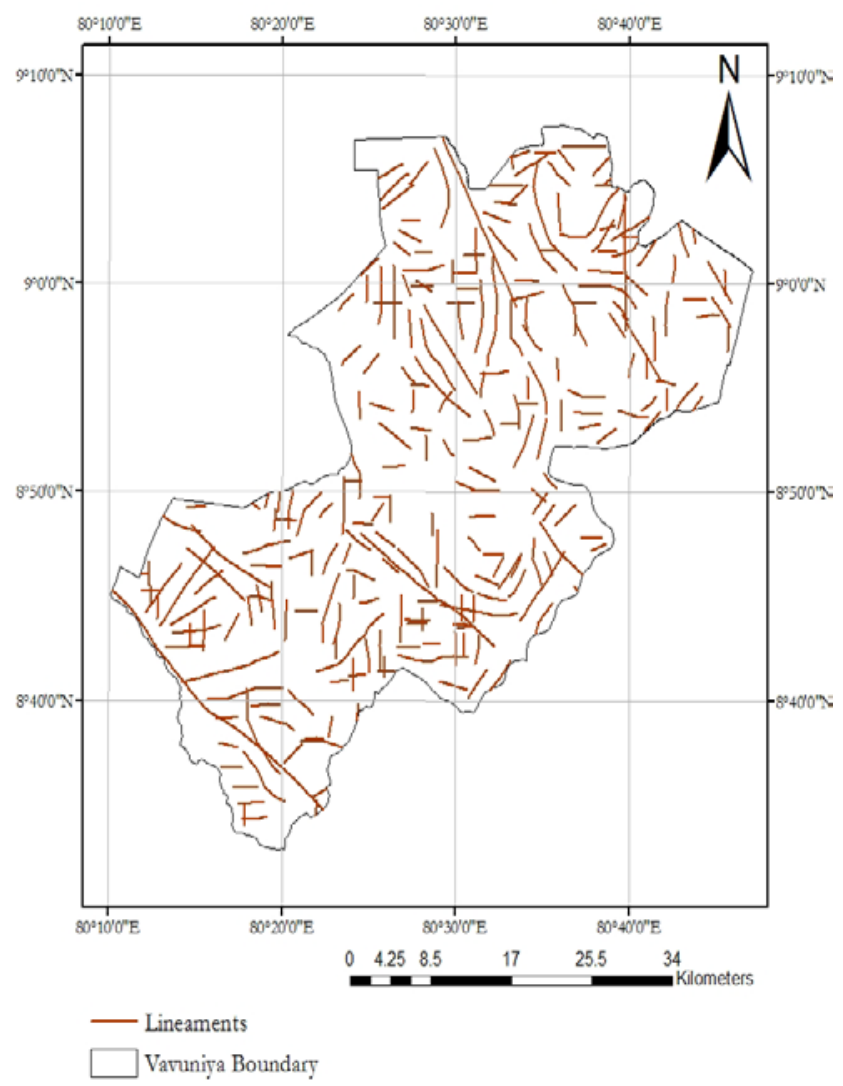

Fig. 3. Lineament Map
Solonetz \& Solonchaks: flat terrain, Alluvial soils of variable texture and drainage: flat terrain, Eroded land, Erosoinal remnants (Inselbergs) were found in the study area. Alluvial soils tend to contribute more to groundwater potential than reddish brown earth soil. Erosional remnants and eroded land designate the isolated bedrock-controlled hills and ridges that rise steeply from the general level of the mantled plain. So the groundwater recharge potential in erosional remnant was low due to the runoff water from the steepness. Fig.6 shows the soil map of study area.

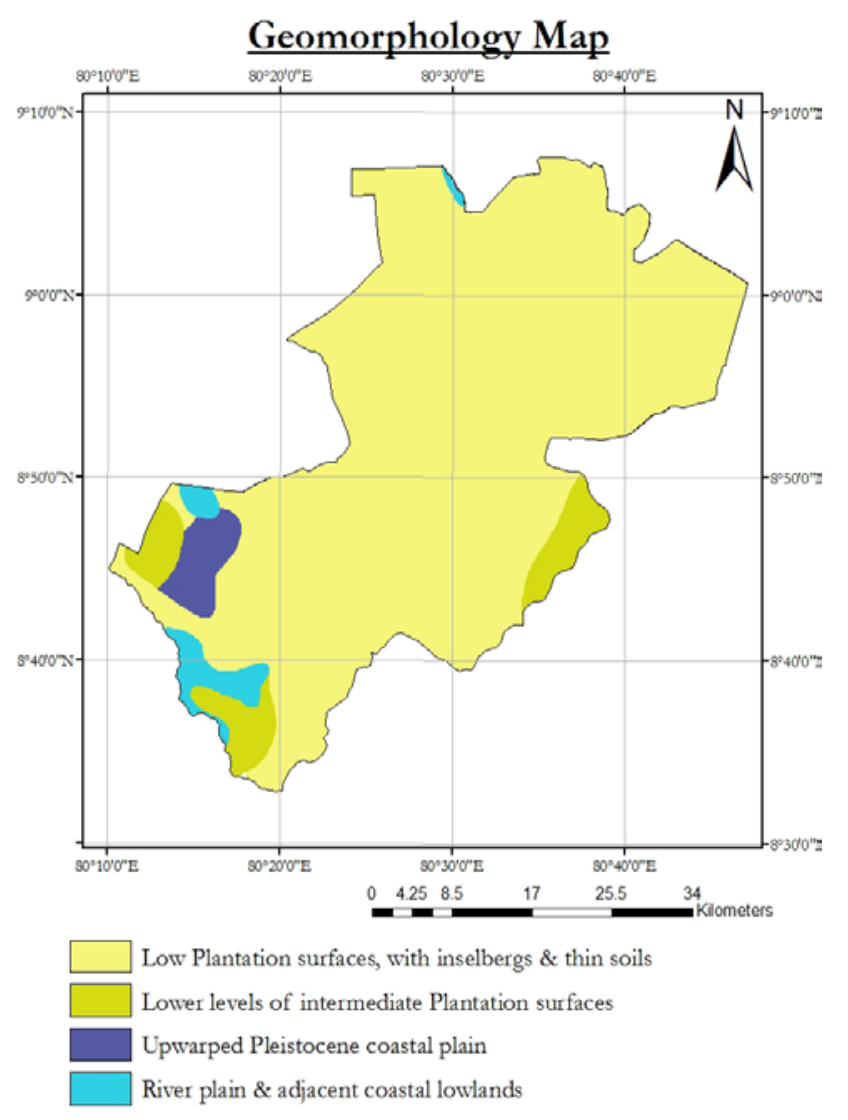

Fig. 4. Geomorphology Map 


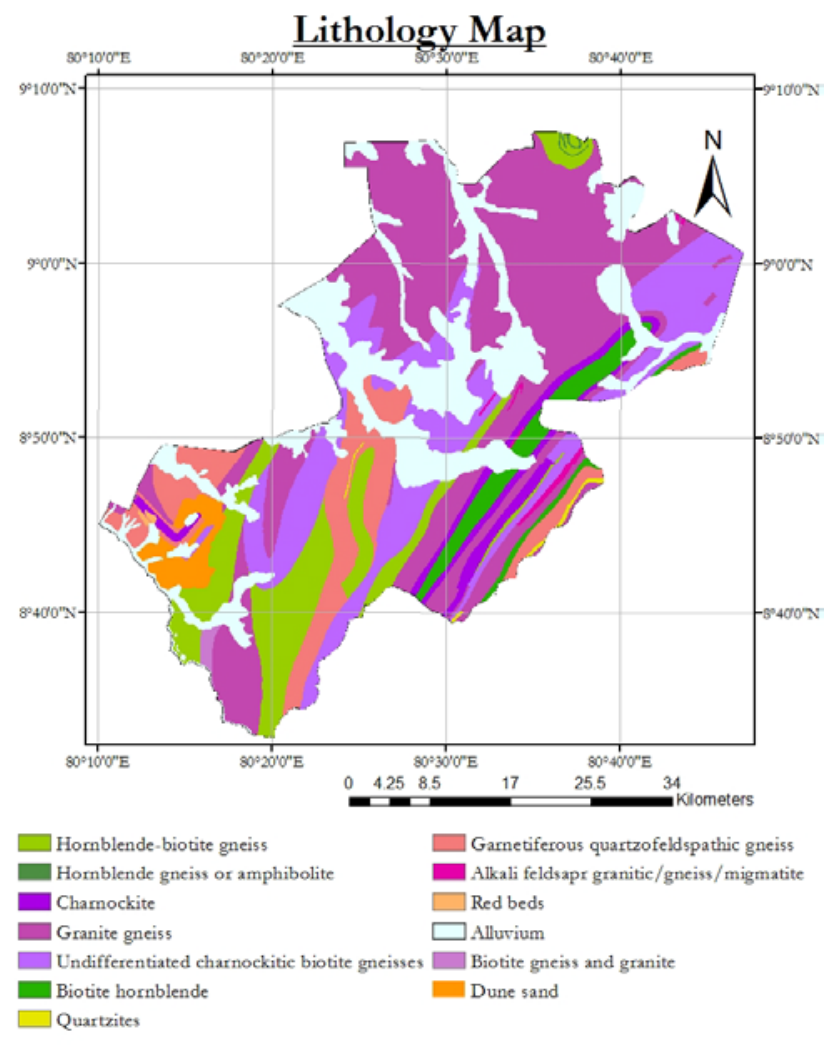

Fig. 5. Lithology Map

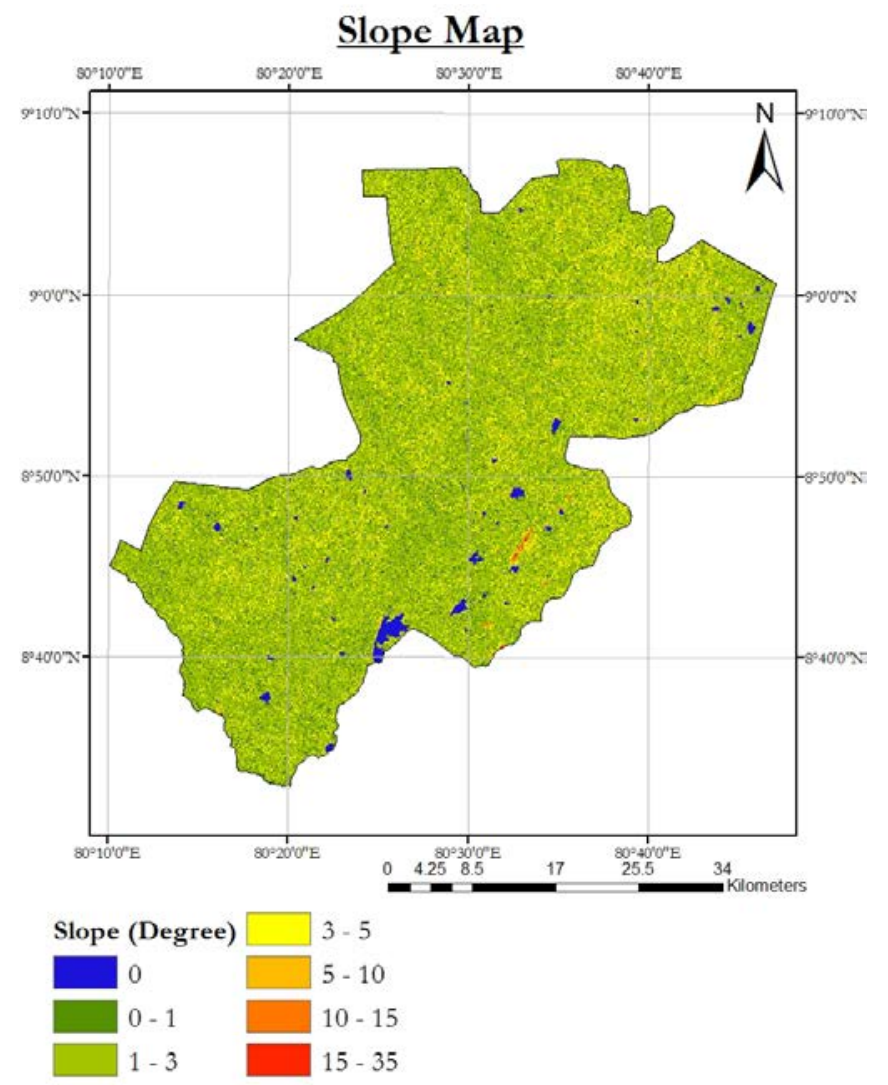

Fig. 7. Slope Map

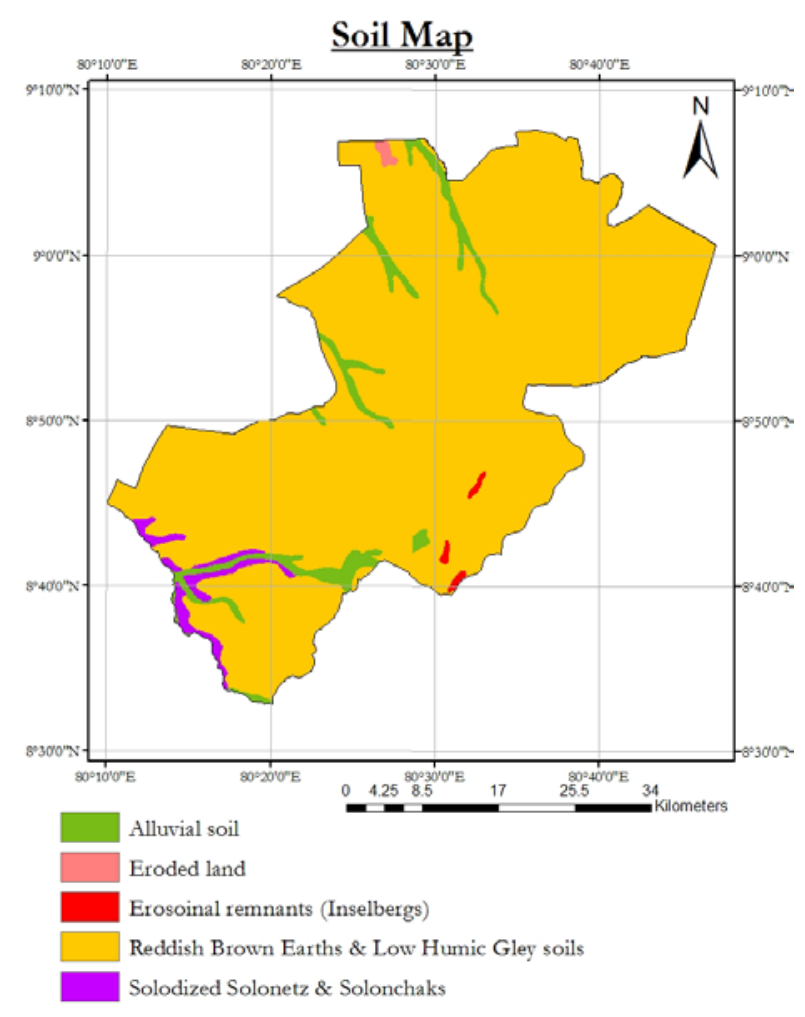

Fig. 6. Soil Map

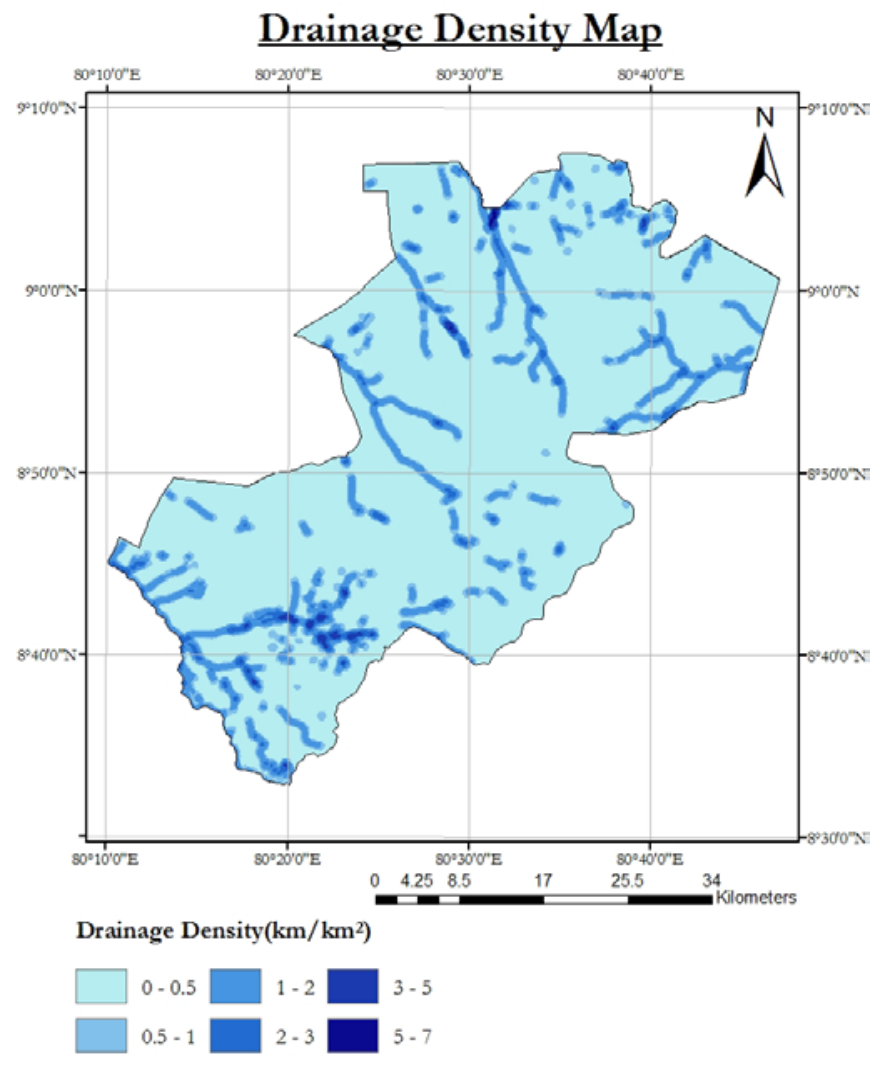

Fig. 8. Drainage density Map 
Lineament Density Map

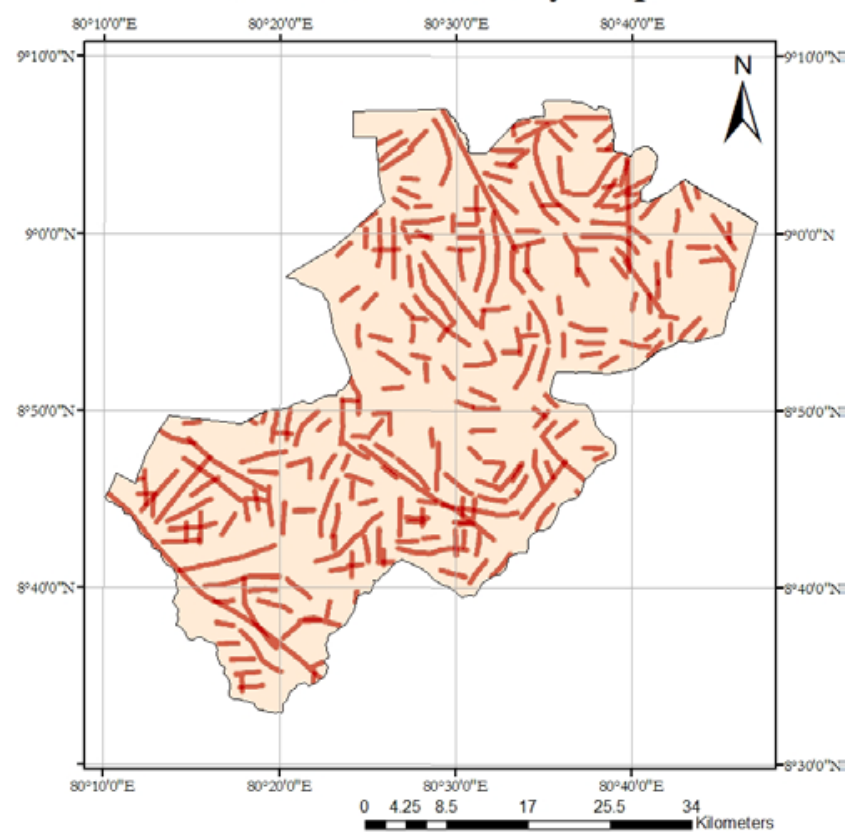

Lineament Density $\left(\mathrm{km} / \mathrm{km}^{2}\right)$

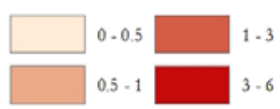

Fig. 9. Lineament Density Map

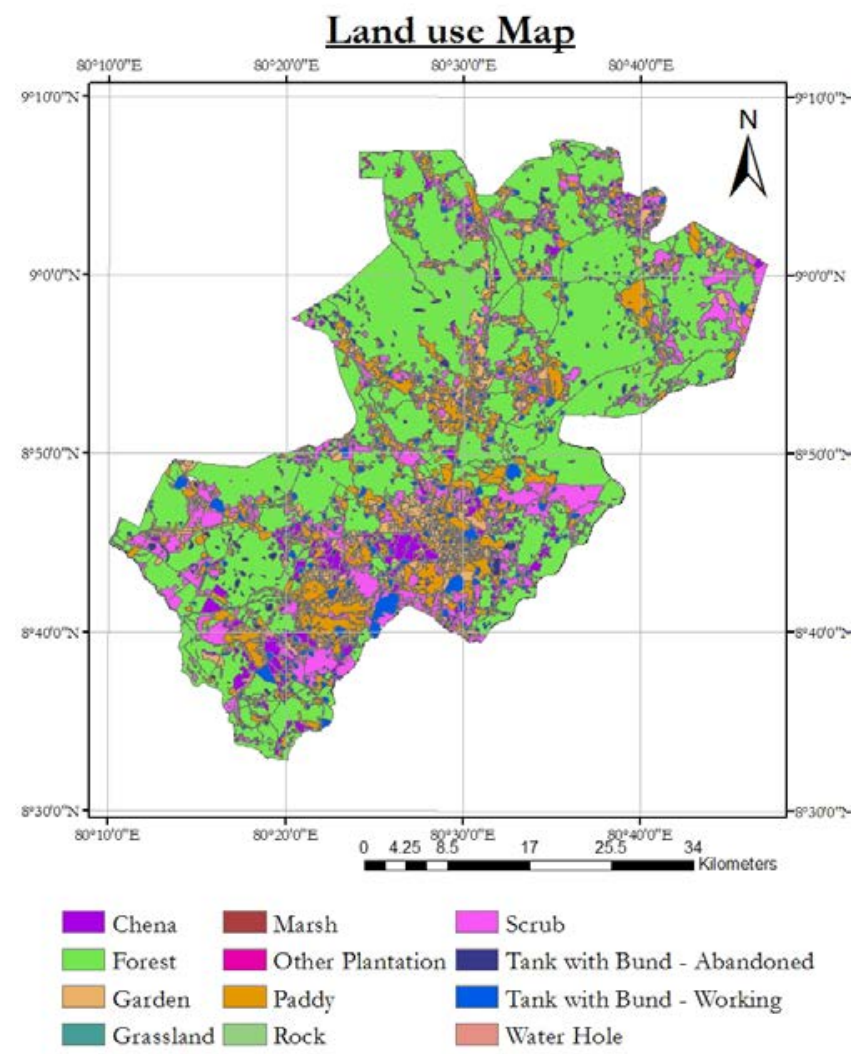

Fig. 10. Land use Map

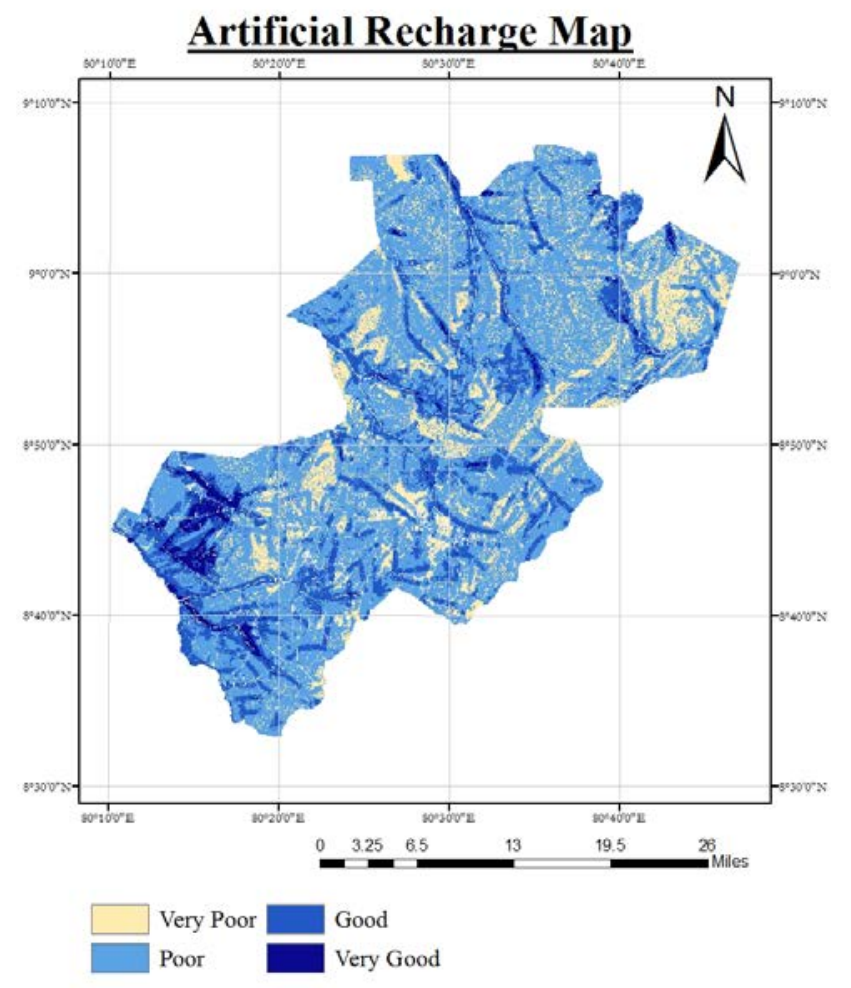

Fig.11. Artificial recharge Map 
Slope plays an important role in ground water recharge. Areas having more than 20 percent slopes had negligible ground water recharge. Major part of the study area had very gentle slope which permit less runoff and had very good recharge potential for ground water. On the other hand, there was an increase in slope towards the Southern part of the study area and gentle slopes were found only in localized pockets. Areas with steep slopes facilitate high runoff and had poor potential for ground water recharge. Fig. 7 shows the slope map of study area.

The overall drainage of the study area showed dendritic pattern. The drainage density map was prepared and it was divided into six classes. The Northern part exhibited coarse drainage density whereas the Southern part showed fine drainage density. Ground water recharge potential is poor in areas with very high drainage density as major part of the rainfall is lost as surface runoff with little infiltration to recharge the ground water. On the other hand, areas with low drainage density allow more infiltration to recharge the ground water and therefore have more potential for ground water. Fig. 8 shows drainage density map of study area.

Lineaments are very important from ground water point of view as they control the movement and storage of ground water. Both major and minor lineaments in the study area were delineated which include faults, fracture, cracks. A lineament density map was prepared and it was divided into 4 classes. Areas with higher lineament density facilitate infiltration and recharge of ground water and therefore have good potential for ground water development. Fig. 9 shows the lineament density map of the study area.

Some land covers make a great impact on infiltration and rain water runoff. Vegetation can slow down the runoff movement, providing more time for runoff water to seep into the ground.
Agriculture and the cultivations of lands also change infiltration patterns of a land. The following classes were distinguished: Plantation, Chena, Forest, Grass Land, Home Garden, Marshy Land, Paddy, Rock, Scrub, Water bodies. Fig. 10 shows the land use map of study area.

Thematic layers were overlayed to produce artificial recharge map in the study area. Artificial recharge was observed high in Southern part of the study area. Fig. 11 shows the artificial recharge map of study area.

The groundwater recharge potential of this study area can be divided into four grades, namely very good, good, poor, and very poor. The artificial recharge map demonstrates that the excellent groundwater potential zone is concentrated in the southern region of the study area. About $35 \%$ of the total area falls under the 'very poor' zone, $15 \%$ falls under 'poor' zone, $44 \%$ falls under 'good' groundwater potential zone, and $6 \%$ of the study area fall under 'very good' zone.

\section{Conclusion}

This study concludes that groundwater recharge potential was high in the Southern part of the study area. Statistically, $6 \%$ of the study area showed 'Very Good' potential and 44\% showed 'Good' potential for groundwater recharge and $15 \%$ of area showed 'Poor' potential and rest showed 'Very Poor' potential.

The GIS model developed in this study can be utilized to find out most suitable locations for groundwater recharge in any area of consideration within a short time by providing the data viz. lithology, geomorphology, soil, land use, stream network, lineaments and slope. Finally, the results of this study can be effectively 
utilized in future developments in the dry zone of the country.

\section{References}

Basavaraj, H. and Nijagunappa, R. (2011). Identification of groundwater potential zone using geoinformatics in Ghataprabha basin, North Karnataka, India. International Journal of Geomatics and Geosciences, 2, 91-109.

European Soil Portal. (2015). The Soil Maps of Asia. Retrieved August 20, 2015, from http:// eusoils.jrc.ec.europa.eu/esdb_arch ive/eudasm/asia/lists/clk.htm

Foster, S. S. (n.d.). UK report No $\mathrm{WD} / 05 / 76 / 4$. Institue of Geological society.

Freeze, A. and Cherry, J. A. (1979). Groundwater. Englewood cliffs: Prentice Hall.

Geological Survey and Mines Bureau of Sri Lanka. (2001). 1:100,000 Geology (Provisional Map Series) Map. Sri Lanka.

Gunawardena, G. W. and Dissanayake, D. O. (2007). Evaluation of Water Scarcity in the Selected Area of Hambantota District Using RS and GIS Technology. 11th International Conference on Sri Lanka Studies.

Jaiswal, R. K., Mukherjee, S., Krishnamurthy, J. and Saxena, R. (2003). Role of remote sensing and GIS techniques for generation of groundwater prospect zones towards rural development- An approach. International Journal of Remote Sensing, 24, 993-1008.

Kumar, P. K., Gopinath, G. and Seralathan, P. (2007). Application of remote sensing and GIS for the demarcation of groundwater potential zones of a river basin in Kerala, southwest coast of India. International Journal of Remote Sensing, 5583-5601.
Land Use division- Department of Irrigation. (1988). Soil Map of Sri Lanka. Sri Lanka and IT, Netherlands.

Madduma Bandara, C. M. (n.d.). A study of the practice of well irrigation in the country around Vavuniya in Northern Sri Lanka. Sri Lanka Journal of Social Sciences.

Nagaraj, B. S. and Dewan, R. L. (1972). Theoretical and Experimental aspects of the rice of groundwater due to canal irrigation. proceedings of symposium of water logging. New Delhi, India: Central Board of Irrigation and Power. 69 - 78.

Panabokke, C. R and Perera, A. (2005). Ground Water Resources of Sri Lanka. Retrieved october 15, 2015

Prickett, T. A. and Lonnquist, C. G. (1971). Selected Digital Computer Techniques for Groundwater Resource Evaluation. State Water Survey Division.

Raghunath, H. M. (1987). Ground water (2nd ed.). New Age International.

Sarup, J., Tiwari, M. K. and Khatediya, V. (2011). Delineate groundwater prospect zones and identification of artificial recharge sites using geospatial technique. International Journal of Advance Technology $\mathcal{E}$ Engineering Research, 6-20.

Senanayake, I. P., Dissanayake, D., Mayadunna, B. B. and Weerasekera, W. L. (2015). An approach to delineate groundwater recharge potential sites in Ambalantota, Sri Lanka using GIS techniques. Geoscience Frontiers, 1-10.

Shahid, S., Nath, S. K. and Roy, J. (2000). Groundwater potential modelling in a soft rock area using a GIS. International Journal of Remote sensing, 21, 1919-1924.

Sivakumar, S. S. (2008). Conjunctive use of surface and groundwater to improve food productivity in a restricted area. Thesis for 
doctor of Philosophy. University of Moratuwa.

Statistical handbook. (2015). Vavuniya: District Secretariat.

Verstappen, H. T. and Hoschtitzky, M. E. (1987). Geomorphological Map of Sri lanka. Netherlands.
W.L. Weerasekara, B.B. Mayadunna, I.P. Senanayake. and D.M.D.O.K. Dissanayake. (2014). Integrated remote sensing and GIS in lineament mapping for groundwater exploration-A case study in Ambalantota, Sri Lanka. Proceeding of SAITM Research Symposium on Engineering Advancements 2014, South Asian Institute of Technology and Medicine, 62-65. 